\title{
PENGARUH PEMBERIAN PENGHARGAAN TERHADAP KINERJA PEGAWAI DI DINAS KEBUDAYAAN DAN PEMUDA KABUPATEN ACEH BARAT
}

\author{
Mursyidin \\ Fakultas Ilmu Sosial dan Ilmu Politik, Universitas Malikussaleh, Aceh Utara \\ mursyidinza@yahoo.com
}

\begin{abstract}
The awarding of employee service, aiming to motivate the passion and loyalty. The award, a government effort to provide remuneration or the work of employees, so as to encourage employees to be more enterprising and achievement. The award was in recognition of an achievement that has been achieved by a person, who will be a strong motivator. While the performance of employees, is the result of work achieved in executing the duties or responsibilities assigned to them, which are based on the timeliness, quality work. In this study, the authors use quantitative data analysis, namely data processing in the form of numbers, whether as a result of measurement and results. Kompensi, more widely used in research because it produces a more precise conclusion, compared with qualitative analysis techniques. Based on the results of research conducted, the results of coefficient $r=0.574$ and $r$ arithmetic tables 0.266 (0.574> 0.266), it can be concluded that there is a positive relationship between the awarding of the performance of employees, the Department of Education Culture Youth and Sports. From the table data classification determines that the award in the cultural education offices Youth and Sports, at the high category. This shows that the award to the Department of Education Culture Youth and Sport has been good, while for the result of the impact of the award on employee performance is pa6da very high category. Researchers found that employees expect every year, Head of promoting employee or proposed employee in order to get the award. Given to every employee job performance, will improve the performance of the duties in their respective fields.
\end{abstract}

Keywords: awards, performance, employee 


\section{PENDAHULUAN}

Menurut Handoko (2000:167) yaitu pemberian penghargaan dari pemerintah kepada pegawai berdasarkan prestasi, masa kerja dan pengabdian akan dijadikan teladan bagi pegawai lainnya. Dalam meningkatkan kinerja pegawai, pemerintah menempuh beberapa cara misalnya; melalui pendidikan, pelatihan, pemberian kompensasi yang layak, menciptakan lingkungan kerja yang kondusif dan pemberian motivasi. Melalui proses-proses tersebut, pegawai diharapkan akan lebih memaksimalkan tanggung jawab atas pekerjaan mereka. hal ini dikarenakan para pegawai telah memperoleh bekal dari proses pendidikan dan pelatihan yang akan menunjang kualitas pekerjaan.

Penelitian ini dilaksanakan karena sangat penting untuk memotivasi para pegawai sehingga pegawai merasa lebih diperhatikan dan dihargai oleh instansi. Sebagai manusia, kita pasti merasa bangga terhadap lingkungan kerja jika mendapatkan predikat yang istimewa, maka pasti menambah motivasi dan semangat kerja agar tercipta prestasi pribadi pegawai yang tanpa disadari juga meningkatkan kualitas daya saing antarpegawai dalam bekerja efektif dan berkualitas serta meningkatkan kualitas instansi.

Pemberian penghargaan kepada pegawai bertujuan untuk memotivasi gairah dan loyalitas instansi. Pemberian penghargaan tersebut merupakan upaya pemerintah dalam memberikan balas jasa atau hasil kerja pegawai sehingga dapat mendorong pegawai untuk lebih giat dan berprestasi.

Dalam beberapa hasil penelitian terdahulu, penulis menemukan pentingnya persoalan pemberian penghargaan kepada pegawai yang bisa memberikan dampak positif terhadap kinerja, seperti yang diungkapkan oleh, Warsidi (2004) yang meneliti tentang "Pengaruh Kompensasi dan Kepuasan Kerja Terhadap Kinerja Guru“ dengan menggunakan Metode Analisis Regresi Linier Berganda. Hasil penelitian tersebut menunjukkan bahwa kompensasi berpengaruh positif dan signifikan terhadap kinerja guru, begitu juga dengan kepuasan kerja berpengaruh positif dan signifikan terhadap kinerja guru.

Selain itu, Anoki Herdian Dito (2010) dengan judul "Pengaruh Kompensasi Terhadap Kinerja Karyawan" dengan menggunakan Metode Analisis Regresi Linier Berganda. Hasil penelitian menunjukkan bahwa kompensasi berpengaruh positif dan signifikan terhadap kinerja, sehingga adanya peningkatan pemberian kompensasi akan meningkatkan kinerja karyawan. Kompensasi berpengaruh tidak langsung terhadap kinerja melalui motivasi kerja, sehingga dapat disimpulkan bahwa motivasi kerja menjadi variabel yang memediasi hubungan antara kompensasi terhadap kinerja karyawan.

Siswanto (2000:245) mengemukakan pengertian dari penghargaan adalah pengakuan atas suatu prestasi yang telah dicapai oleh seseorang dan merupakan media motivator yang kuat. Pengakuan atas suatu prestasi akan memberikan keputusan yang lebih tinggi daripada pemberian secara tak beralasan atau cuma-cuma.

Jenis-jenis penghargaan terdiri dari beberapa jenis, sebagaimana yang dikemukakan oleh Siswanto (2000:268) yaitu terdiri dari 4 (empat), yaitu :

a. Penghargaan Masa Kerja, yaitu penghargaan yang diberikan oleh perusahaan kepada pegawai terhitung 5 tahun setelah pegawai yang bersangkutan masuk kerja, untuk selanjutnya pegawai berhak memperoleh penghargaan masa kerja.

b. Penghargaan Pengabdian, yaitu penghargaan yang diberikan pada pegawai yang dihentikan dengan hak pensiun serta telah menunjukkan pengabdian kepada pemerintah pada masa kerja minimal 30 tahun.

c. Penghargaan atas Prestasi, yaitu pemberian penghargaan kepada pegawai yang komponen penggajiannya tidak terdapat unsur premi prestasi.

d. Penghargaan Akhir Jabatan, yaitu pemberian penghargaan yang diberikan pada pegawai yang telah mengakhiri masa kerjanya. 
Penghargaan mempunyai berbagai bentuk yang diberikan kepada pegawai, sebagaimana yang disebutkan oleh Siswanto (2000:275), yaitu:

a. Bintang Jasa, yaitu salah satu bentuk penghargaan yang berupa lencana, biasanya diberikan kepada pegawai yang telah memberikan jasa yang besar bagi kemajuan kantor.

b. Piagam Penghargaan, yaitu bentuk penghargaan yang pada umumnya berupa surat keterangan yang menerangkan bahwa pegawai tersebut telah memperoleh penghargaan atas prestasi kerjanya.

c. Kenaikan gaji istimewa, yaitu bentuk penghargaan yang diberikan kepada pegawai yang mempunyai nilai "amat baik" dalam melaksanakan pekerjaannya sehingga ia patut dijadikan pegawai yang teladan bagi pegawai lainnya.

d. Kenaikan Pangkat Istimewa, yaitu suatu bentuk penghargaan yang diberikan kepada pegawai yang menunjukkan prestasi kerja yang luar biasa sehingga layak mendapatkan kenaikan pangkat.

e. Uang, yaitu suatu penghargaan yang diberikan kepada pegawai dalam bentuk uang yang disesuaikan dengan peraturan yang berlaku.

Menurt Dessler (2000:89) ada lima faktor dalam penilaian kinerja yang populer, yaitu:

a. Prestasi pekerjaan, meliputi: akurasi, ketelitian, keterampilan, dan penerimaan keluaran

b. Kuantitas pekerjaan, meliputi: volume keluaran dan kontribusi

c. Kepemimpinan yang diperlukan, meliputi: membutuhkan saran, arahan atau perbaikan

d. Kedisiplinan, meliputi: kehadiran, sanksi, warkat, regulasi, dapat dipercaya/ diandalkan dan ketepatan waktu

e. Komunikasi, meliputi: hubungan antar karyawan maupun dengan pimpinan, media komunikasi.

Handoko (2000:78) menyebutkan bahwa penilaian kinerja terdiri dari 3 kriteria, yaitu :

a. Penilaian berdasarkan hasil yaitu penilaian yang didasarkan adanya target dan ukurannya spesifik serta dapat diukur.

b. Penilaian berdasarkan perilaku yaitu penilaian perilaku-perilaku yang berkaitan dengan pekerjaan.

c. Penilaian berdasarkan judgement yaitu penilaian yang berdasarkan kualitas pekerjaan, kuantitas pekerjaan, koordinasi, pengetahuan pekerjaan dan ketrampilan, kreativitas, semangat kerja, kepribadian, keramahan,

Tujuan yang ingin dicapai dalam penelitian ini adalahh mengetahui pengaruh pemberian penghargaan terhadap kinerja pegawai pada Dinas Pendidikan Kebudayaan Pemuda dan Olahraga Kabupaten Aceh Barat.

\section{METODOLOGI PENELITIAN}

Jenis Penelitian

Jenis penelitian yang cocok dengan tujuan penelitian tersebut adalah analisis data kuantitatif, yaitu mengolah data yang berbentuk angka baik sebagai hasil pengukuran maupun hasil kompensasi. Metode tersebut lebih banyak digunakan dalam penelitian karena menghasilkan kesimpulan yang lebih tepat dibandingkan dengan teknik analisis kualitatif (Notoatmodjo 2005:189).

\section{Lokasi Penelitian}

Penelitian ini dilakukan pada Dinas Pendidikan Kebudayaan Pemuda dan Olahraga Kabupaten Aceh Barat di Jl. Bakti Pemuda, No 1, Desa Seunebok Kabupaten Aceh Barat. 


\section{Populasi dan Sampel}

Menurut Sugiyono (2005:90) Populasi adalah wilayah generasi yang terdiri atas subjek/objek yang mempunyai kualitas dan karakteristik tertentu yang ditetapkan oleh peneliti untuk dipelajari dan kemudian ditarik kesimpulannya. Keseluruhan objek yang menjadi sumber data dalam penelitian ini adalah Pegawai Dinas Pendidikan Kebudayaan Pemuda dan Olahraga Kabupaten Aceh Barat dan sedang mendapat tugas pada saat dilaksanakannya penelitian ini. Berdasarkan ciri-ciri atau karakteristik di atas, ternyata jumlah populasi yang tersedia di lingkungan Kantor Dinas Pendidikan Kebudayaan Pemuda dan Olahraga adalah 113 orang pegawai. Selanjutnya, Sugiyono (2005:91) menjelaskan bahwa sampel adalah bagian dari jumlah dan karakteristik yang dimiliki oleh populasi tersebut. Menurut Notoatmodjo (2005:92) untuk populasi kecil atau lebih kecil dari 10.000, dapat menggunakan formula yang lebih sederhana yaitu :

$$
\begin{aligned}
& n=\frac{N}{1+N\left(d^{2}\right)} \\
& =\frac{113}{1+113\left(0,1^{2}\right)} \\
& =\frac{113}{1+113(0,01)} \\
& =\frac{113}{2,13} \\
& =53
\end{aligned}
$$

Persamaan (1)

Keterangan:

$\mathrm{N} \quad=$ besar sampel

$\mathrm{n} \quad=$ besar populasi

$\mathrm{d}=$ tingkat kepercayaan/ketepatan yang diinginkan

\section{Jenis Data dan Teknik Pengumpulan Data}

Jenis data yang digunakan dalam penelitian ini adalah:

1. Data primer, yaitu data yang diperoleh dari responden dengan menggunakan kuesioner, wawancara dan observasi.

2. Data sekunder, yaitu data yang dikumpulkan dari instansi/unit kerja Pemerintah Daerah Kabupaten Aceh Barat, Dinas Pendidikan, Bagian Keuangan, Bagian Kepegawaian. Jenis data sekunder yang dibutuhkan adalah:

a. Data pegawai; umur, jenis kelamin

b. Data tentang peraturan dan kebijaksanaan yang dikeluarkan oleh pemerintah.

c. Jumlah dana untuk Dinas Pendidikan baik rutin maupun pembangunan.

d. Jumlah sarana dan prasarana yang ada.

\section{Teknik Pengukuran Skor}

Sugiyono (2005:108) menyatakan bahwa teknik pengukuran skor atau nilai yang digunakan dalam penelitian ini adalah memakai skala ordinal untuk menilai jawaban kuisioner yang disebarkan kepada responden. Skala ordinal adalah skala yang membedakan kategori berdasarkan tingkat atau urutan.

Adapun penentuan skor dari setiap pertanyaan dengan alternatif jawaban yang berbeda, yaitu :

1) Untuk alternatif jawaban "a" diberi skor tertinggi : 5 
2) Untuk alternatif jawaban "b" diberi skor tinggi : 4

3) Untuk alternatif jawaban "c" diberi skor sedang : 3

4) Untuk alternatif jawaban "d" diberi skor rendah : 2

5) Untuk alternatif jawaban "e" diberi skor terendah : 1

Kemudian untuk menentukan kategori jawaban responden terhadap masing-masing alternatif termasuk ke dalam kelompok sangat tinggi, tinggi, sedang, rendah, sangat rendah, dapat ditentukan kelas intervalnya, dengan cara sebagai berikut:

\section{Skor tertinggi - skor terendah banyak bilangan}

(Persamaan 2)

Maka diperoleh :

$$
\frac{5-1}{5}=0.80
$$

Dengan demikian dapat diketahui kategori jawaban responden masing-masing variabel yaitu:
a. Skor untuk kategori sangat tinggi
$=4,21-5.00$
b. Skor untuk kategori tinggi
$=3,41-4,20$
c. Skor untuk kategori sedang
$=2,61-3,40$
d. Skor untuk kategori rendah
$=1,81-2,60$
e. Skor untuk kategori sangat rendah$$
=1,00-1,80
$$

\section{Analisis Data}

Teknik analisa data yang digunakan penulis adalah teknik analisa data kuantitatif, yaitu analisa yang digunakan untuk menguji hubungan atau pengaruh variabel bebas $(\mathrm{X})$ dan variabel terikat (Y), yaitu dengan menggunakan instrumen:

1. Koefisien korelasi product moment

Cara ini digunakan untuk mengetahui ada atau tidaknya dan besar kecilnya hubungan antara variabel maka digunakan rumus sebagai berikut, Sugiyono (2005:212).

$r_{x y}=\frac{N \sum x y-\left(\sum x\right)\left(\sum y\right)}{\sqrt{\left\{N \sum x^{2}-\left(\sum x\right)^{2}\right\}\left\{N \sum y^{2}-\left(\sum y\right)^{2}\right\}}}$

(persamaan 3)

Keterangan :

$\mathrm{r}_{\mathrm{xy}} \quad=$ angka indeks korelasi

$\mathrm{N} \quad=$ ukuran sampel

$\sum \mathrm{xy}=$ jumlah hasil perkalian antara skor $\mathrm{X}$ dan skor $\mathrm{Y}$

$\sum \mathrm{x} \quad=$ jumlah seluruh skor $\mathrm{X}$

$\sum \mathrm{y} \quad=$ jumlah seluru skor $\mathrm{Y}$

2. Koefisien determinan

Koefisien determinan digunakan untuk mengetahui seberapa besar (persentase) pengaruh yang ditimbulkan oleh variabel bebas terhadap variabel terikat. Rumus yang digunakan adalah sebagai berikut:

$$
D=\left(r^{2}\right) \times 100 \%
$$

Persamaan (4)

Keterangan :

D: koefisien determinan

$\mathrm{r}$ : koefisien korelasi product moment 


\section{HASIL DAN PEMBAHASAN}

Dalam pengumpulan data penelitian digunakan teknik kuisioner yaitu dengan menyebarkan sejumlah pertanyaan kepada para pegawai yang berjumlah 53 orang dan telah ditetapkan sebagai responden.

\section{Deskripsi Data Identitas Responden}

Data identitas responden mencakup distribusi data responden berdasarkan jenis kelamin dan umur. Berdasarkan hasil penelitian yang telah dilakukan, maka identitas responden dapat diuraikan sebagai berikut :

Tabel 1. Jenis Kelamin Responden

\begin{tabular}{|c|l|c|c|}
\hline No & \multicolumn{1}{|c|}{ Jenis Kelamin } & Jumah (orang) & Persentase (\%) \\
\hline 1 & Laki-Laki & 33 & $62,26 \%$ \\
2 & Perempuan & 20 & $37,73 \%$ \\
\hline & Total & 53 & $100 \%$ \\
\hline
\end{tabular}

Sumber: Angket 2011

Berdasarkan Tabel 3.1 dapat diketahui bahwa pegawai laki-laki berjumlah $33(62,26 \%)$ dan pegawai perempuan berjumlah $20(37,73 \%)$. Dengan demikian dapat disimpulkan bahwa responden umumnya adalah laki-laki.

Tabel 2. Umur Responden

\begin{tabular}{|c|l|c|c|}
\hline No & \multicolumn{1}{|c|}{ Kelompok Umur } & Jumlah (orang) & Persentase (\%) \\
\hline 1 & $20-30$ Tahun & 18 & 33,96 \\
2 & $31-40$ Tahun & 10 & 18,86 \\
3 & $41-50$ Tahun & 17 & 32,07 \\
4 & 51 tahun keatas & 8 & 15,09 \\
\hline & Total & 53 & 100 \\
\hline
\end{tabular}

Sumber : Angket 2011

Berdasarkan pada Tabel 3.2 diketahui bahwa yang menjadi responden terbanyak dalam penelitian ini adalah dengan karakteristik umur di antara 20-30 yaitu sebanyak 18 orang $(33,96 \%)$ kemudian yang berumur antara 41-50 sebanyak 17 orang $(32,07 \%)$ kemudian yang berumur antara $31-40$ yaitu sebanyak 10 orang $(18,86 \%)$ sedangkan karakteristik yang berumur $51>$ yaitu sebanyak 8 orang $(15,09 \%)$.

\section{Penghargaan}

Untuk mengetahui pengaruh pemberian penghargaan terhadap kinerja pegawai pada Dinas Pendidikan Kebudayaan Pemuda dan Olahraga maka dibutuhkan pengkategorian jawaban responden. Pengkategorian tersebut dilakukan dengan menggunakan jawaban respoden terhadap kuesioner yang diberikan, kemudian diklarifikasi menggunakan rumus Teknik Pengukuran Skor yang terdapat pada bab metode penelitian. Sehingga dihasilkan data olahan sebagai berikut:

Tabel 3. Distribusi frekuensi klasifikasi jawaban responden mengenai

Pengaruh Pemberian Penghargaan Terhadap Kinerja Pegawai

\begin{tabular}{|c|l|c|c|}
\hline Nilai Jawaban & \multicolumn{1}{|c|}{ Kategori } & Frekuensi & Persentase (\%) \\
\hline $4,21-5,00$ & sangat tinggi & 21 & 39,62 \\
$3,41-4,20$ & tinggi & 26 & 49,05 \\
$2,61-3,40$ & Sedang & 6 & 11,32 \\
$1,81-2,60$ & Rendah & - & - \\
$1,00-1,80$ & Sangah rendah & - & - \\
\hline Jumlah & & $\mathbf{5 3}$ & $\mathbf{1 0 0}$ \\
\hline
\end{tabular}

Sumber : Penelitian Tahun 2011 
Berdasarkan Tabel 3.3 diketahui bahwa jawaban responden berada pada kategori sangat tinggi yaitu sebanyak 21 orang $(39,62 \%)$, kategori tinggi sebanyak 26 orang $(49,05 \%)$, kategori sedang sebanyak 6 orang $(11,32 \%)$, sedangkan untuk kategori rendah dan sangat rendah tidak ada. Hal ini menunjukkan bahwa pemberian penghargaan terhadap pegawai di Dinas Pendidikan kebudayaan Pemuda dan Olahraga berada pada kategori tinggi. Hal ini menunjukkan bahwa pegawai di dinas tersebut secara umum telah mengerti akan pentingnya pengaruh pemberian penghargaan terhadap kinerja pegawai.

Kesimpulannya pemberian penghargaan sangat berpengaruh pada Dinas Pemdidikan Kebudayaan Pemuda dan Olahraga. Dengan adanya pemberian penghargaan dapat memotivasi pegawai untuk bekerja dengan semnagat tinggi dalam mendedikasikan diri sebagai pegawai di dinas tersebut. Disamping itu, faktor nepotisme tidak menjadi suatu parameter dalam memperoleh penghargaan. Sehingga, timbul persaingan antar pegawai dengan sportif untuk bekerja dengan semangat tinggi agar mendapatkan penghargaan.

\section{Kinerja Pegawai}

Kinerja pagawai pada Dinas Pendidikan Kebudayaan Pemuda dan Olahraga dapat dilihat pada tabel di bawah ini. Berdasarkan Tabel 3.4 diketahui bahwa jawaban responden berada pada kategori sangat tinggi yaitu sebanyak 32 orang $(60,37 \%)$, kategori tinggi sebanyak 17 orang $(32,07 \%)$, untuk kategori sedang sebanyak 4 orang $(7,54 \%)$ serta untuk kategori rendah dan sangat rendah tidak ada.

Tabel 4. Distribusi frekuensi klasifikasi jawaban responden mengenai Dampak kinerja pegawai pada Dinas Pendidikan Kebudayaan Pemuda dan Olahraga

\begin{tabular}{|c|c|c|c|}
\hline Nilai Jawaban & Kategori & Frekuensi & Persentase (\%) \\
\hline $4,21-5,00$ & Sangat tinggi & 32 & 60,37 \\
$3,41-4,20$ & Tinggi & 17 & 32,07 \\
$2,61-3,40$ & Sedang & 4 & 7,54 \\
$1,81-2,60$ & Rendah & - & - \\
$1,00-1,80$ & Sangat rendah & - & - \\
\hline Jumlah & & $\mathbf{5 3}$ & $\mathbf{1 0 0}$ \\
\hline
\end{tabular}

Sumber : Penelitian tahun 2011

Hal ini menunjukkan bahwa dampak pemberian penghargaan terhadap kinerja pegawai berada pada kategori sangat tinggi. Kesimpulannya bahwa dengan adanya pemberian penghargaan memberikan dampak positif kepada pegawai untuk meningkatkan kinerjanya, yang diwujudkan dengan kedisiplinan yang tinggi dalam menjalankan tugas sesuai tupoksinya. Disamping itu, pemberian penghargaan juga memberikan dampak yang besar yakni munculnya ide-ide kreatif di antara pegawai dalam mengembangkan program kerja yang ada, kerja sama di antara sesama pegawai tercipta, dan mengerjakan tugas tepat waktu. Sehingga metode pemberian penghargaan kepada pegawai tersebut perlu dilanjutkan dan ditingkatkan untuk meningkatkan kualitas pegawai dan instansi tentunya.

\section{Pengujian Hipotesa}

Dalam pengujian hipotesis tersebut digunakan uji Korelasi Pearson Product Moment untuk menentukan atau mengetahui besarnya pengaruh koefisien korelasi antara dua variabel. Berikut langkah-langkah pengolahan data kuantitatif berdasarkan data responden:

Diketahui bahwa:

$$
\begin{array}{ll}
\mathrm{N} & =53 \\
\Sigma \mathrm{X} & =2285
\end{array}
$$


$\begin{aligned} \sum \mathrm{Y} & =1987 \\ \sum \mathrm{X}^{2} & =99729 \\ \sum \mathrm{Y}^{2} & =75431 \\ \sum \mathrm{XY} & =86279\end{aligned}$

Kemudian hasil tersebut dimasukkan ke dalam rumus Korelasi Pearson Product Moment, maka didapatkan hasil sebagai berikut :

$$
\begin{gathered}
r_{x y}=\frac{N \sum x y-\left(\sum x\right)\left(\sum y\right)}{\sqrt{\left\{N \sum x^{2}-\left(\sum x\right)^{2}\right\}\left\{N \sum y^{2}-\left(\sum y\right)^{2}\right\}}} \\
=\frac{(53 \times 86279)-(2285 \times 1987)}{\sqrt{\left\{(53 \times 99729)-(2285)^{2}\right\}\left\{(53 \times 75431)-(1987)^{2}\right\}}} \\
=\frac{4572787-4540295}{\sqrt{(5285637-5221225)(3997843-3948169)}} \\
=\frac{32492}{\sqrt{(64412)(49674)}} \\
=\frac{32492}{\sqrt{3199601688}} \\
=\frac{32492}{56565} \\
=0.574
\end{gathered}
$$

Setelah diuji secara empiris, maka hipotesa yang diajukan dapat diterima dan tidak menyimpang dari kerangka teori. Hal ini berarti pengaruh pemberian penghargaan mempunyai hubungan yang positif dengan kinerja pegawai pada Dinas Pendidikan Kebudayaan Pemuda dan Olahraga.

Dari hasil perhitungan yang menggunakan rumus Korelasi Pearson Product Moment, maka didapat hasil koefisien korelasi sebesar 0,574. Dalam penentuan signifikan antara pengaruh pemberian penghargaan terhadap kinerja pegawai pada Dinas Pendidikan Kebudayaan Pemuda dan Olahraga, dilakukan perbandingan antara $\mathrm{r}$ yang diporeh dengan rumus korelasi product moment dengan $\mathrm{r}$ pada tabel ( $\mathrm{r}$ tabel). Jika dilihat pada $\mathrm{r}$ tabel koefisien Korelasi Product Moment dengan taraf signifikan 5\% Untuk N=53 diperoleh nilai $\mathrm{r}$ tabel = 0,279.

Jika dibandingkan dengan nilai $\mathrm{r}$ yang diperoleh dari hasil perhitungan rumus tersebut, maka nilai $r$ yang diperoleh lebih besar dibandingkan $r$ tabel $(0,574>0,279)$, maka dapat disimpulkan bahwa terdapat hubungan positif antara pemberian penghargaan terhadap kinerja pegawai pada Dinas Pendidikan Kebudayaan Pemuda dan Olahraga. Dengan demikian semakin banyak penghargaan yang diberikan maka semaikin baik pula kinerja pegawai. Dengan kata lain adalah apabila salah satu variabel mengalami peningkatan, maka variabel yang berkorelasi juga mengalami peningkatan dan begitu juga sebaliknya, apabila salah satu variabel mengalami penurunan maka variabel yang berkorelasi juga akan mengalami penurunan.

Berdasarkan hasil-hasil yang dikemukakan di atas, maka hipotesa yang dikemukakan ini dapat diterima yaitu terdapat pengaruh positif antara pemberian penghargaan dengan kinerja pegawai pada Dinas Pendidikan Kebudayaan Pemuda dan Olahraga. 
Selanjutnya untuk dapat memberikan interpretasi seberapa kuat hubungan tersebut, maka digunakan penafsiran/interpretasi angka yang dikemukakan oleh Sugiyono (2005: 214).

Tabel 5. Pedoman dalam Pemberian Interpretasi Koefisien

\begin{tabular}{|c|c|}
\hline Interval Koefisien & Tingkat Hubungan \\
\hline $0,00-0,19$ & Sangat rendah \\
$0,20-0,39$ & Rendah \\
$0,40-0,59$ & Sedang \\
$0,60-0,79$ & Kuat \\
$0,80-1,00$ & Sangat kuat \\
\hline
\end{tabular}

Sumber : Penelitian Tahun 2011

Melalui interpretasi pada Tabel 3.5 diketahui bahwa tingkat pengaruh pemberian penghargaan terhadap kinerja pegawai pada Dinas Pendidikan kebudayaan Pemuda dan Olahraga berada pada kategori sedang. Dari hasil $r_{x y}$ sebesar 0,547 maka menurut interpretasi di atas jelas menunjukkan adanya korelasi pada interval koefisien 0,40-0,59.

\section{Koefisien Determinan}

Untuk mengetahui seberapa besar pengaruh pemberian penghargaan (variabel bebas $(\mathrm{X})$ ) terhadap kinerja pegawai (variabel terikat $(\mathrm{Y})$ ) dapat dihitung dengan rumus Koefisien Determinan.

$$
\begin{gathered}
D=\left(r_{x y}\right)^{2} \times 100 \% \\
D=(0.574)^{2} \times 100 \% \\
D=0.329 \times 100 \% \\
D=32.9 \%
\end{gathered}
$$

Dari hasil perhitungan di atas maka dapat diketahui bahwa besarnya pengaruh pemberian penghargaan terhadap kinerja pegawai Dinas Pendidikan Kebudayaan Pemuda dan Olahraga adalah sebesar $32,9 \%$ dan $67,1 \%$ Selebihnya dipengaruhi oleh faktor lain yang belum diperhitungkan dalam penelitian ini.

\section{SIMPULAN}

Dari hasil penelitian yang dilakukan pada Dinas Pendidikan kebudayaan Pemuda dan Olahraga Kabupaten Aceh Barat, dapat ditarik kesimpulan sebagai berikut: pertama, Pengaruh pemberian penghargaan pada Dinas Pendidikan Kebudayaan Pemuda dan Olahraga berada pada kategori tinggi. Kedua, Kinerja pegawai pada Dinas Pendidikan Kebudayaan Pemuda dan Olahraga berada pada kategori sangat tinggi. Ketiga, Berdasarkan uji $r_{x y}$ terhadap data menunjukkan bahwa pengaruh pemberian penghargaan terhadap kinerja pegawai pada Dinas Pendidikan Kebudayaan Pemuda dan Olahraga termasuk ke dalam kategori sedang dengan interval koefisien 0.40-0.59. Keempat, Berdasarkan perhitungan determinan (D) maka diketahui pengaruh pemberian penghargaan terhadap kinerja pegawai sebesar 32,9 \% dan $67,1 \%$ dipengaruhi oleh faktor lain yang tidak diteliti dalam penelitian ini.

\section{UCAPAN TERIMA KASIH}

Terima kasih penulis ucapkan kepada setiap pegawai Dinas Pendidikan Kebudayaan Pemuda dan Olahraga Kab. Aceh Barat yang telah menjadi responden dalam penelitian ini.

\section{DAFTAR PUSTAKA}

Dessler. 2000. Penilaian Kinerja. Jakarta : Rineka Cipta.

Handoko, T. Hani. 2000. Manajemen. Jogjakarta: Fakultas Ekonomi Universitas Gajah Mada. Notoatmodjo, Soekidjo. 2005. Metodelogi Penelitian Kesehatan. Jakarta : Rineka Cipta. 
Siswanto, Bedjo. 2000. Manajemen Tenaga Kerja. Surabaya.

Sugiyono. 2005. Metode Penelitian Administrasi. Bandung: Alfabeta.

Warsidi. 2004. Pengaruh Kompensasi dan Kepuasan Kerja terhadap Kinerja Guru.Tesis PPS UPI Bandung: Tidak diterbitkan. 